\title{
Regulatory RNAs: A Universal Language for Inter-Domain Communication
}

\author{
Emma Layton ${ }^{1}$ D , Anna-Marie Fairhurst ${ }^{2}$, Sam Griffiths-Jones ${ }^{1,3}$, Richard K. Grencis ${ }^{1, *}$ and \\ Ian S. Roberts $1, *$ \\ 1 Lydia Becker Institute of Immunology and Inflammation, Division of Infection, Immunity and Respiratory \\ Medicine, School of Biological Sciences, Faculty of Biology Medicine and Health, University of Manchester, \\ Manchester M13 9PT, UK; emma.layton@postgrad.manchester.ac.uk (E.L.); \\ Sam.Griffiths-Jones@manchester.ac.uk (S.G.-J.) \\ 2 Institute of Molecular and Cell Biology, A*STAR, 61 Biopolis Drive, Singapore 138673, Singapore; \\ annamarie@imcb.a-star.edu.sg \\ 3 Division of Evolution and Genomic Sciences, School of Biological Sciences, Faculty of Biology Medicine and \\ Health, University of Manchester, Manchester M13 9PT, UK \\ * Correspondence: richard.grencis@manchester.ac.uk (R.K.G.); i.s.roberts@manchester.ac.uk (I.S.R.)
}

Received: 22 October 2020; Accepted: 20 November 2020; Published: 24 November 2020

\begin{abstract}
In eukaryotes, microRNAs (miRNAs) have roles in development, homeostasis, disease and the immune response. Recent work has shown that plant and mammalian miRNAs also mediate cross-kingdom and cross-domain communications. However, these studies remain controversial and are lacking critical mechanistic explanations. Bacteria do not produce miRNAs themselves, and therefore it is unclear how these eukaryotic RNA molecules could function in the bacterial recipient. In this review, we compare and contrast the biogenesis and functions of regulatory RNAs in eukaryotes and bacteria. As a result, we discovered several conserved features and homologous components in these distinct pathways. These findings enabled us to propose novel mechanisms to explain how eukaryotic miRNAs could function in bacteria. Further understanding in this area is necessary to validate the findings of existing studies and could facilitate the use of miRNAs as novel tools for the directed remodelling of the human microbiota.
\end{abstract}

Keywords: RNA; miRNA; microbiota; communication; extracellular vesicles

\section{Regulatory RNAs in Eukaryotes}

The expansive non-coding regions of eukaryotic genomes are now known to encode many important regulatory elements such as promoters, enhancers and long non-coding RNAs (lncRNAs) that influence the transcription of both protein-coding and non-coding regions [1,2]. Some regions function as post-transcriptional gene expression regulators, such as microRNAs (miRNAs), small interfering RNAs (siRNAs) and P-element-induced wimpy testis (PIWI)-interacting RNAs (piRNAs) that bind to their targets through complementary base pairing (Table 1). 
Table 1. Illustrating the similarities between eukaryotic and bacterial antisense RNA-mediated regulatory pathways.

\begin{tabular}{|c|c|c|c|c|c|c|c|c|c|}
\hline $\begin{array}{c}\text { Eukaryotic } \\
\text { RNA }\end{array}$ & Length & Functions & Mechanisms & Distribution & $\begin{array}{c}\text { Bacterial } \\
\text { RNA }\end{array}$ & Length & Functions & Mechanisms & Distribution \\
\hline miRNA & $\begin{array}{c}21-25 \\
\text { nucleotides }\end{array}$ & $\begin{array}{ll}\text { - } & \text { Translational } \\
& \text { repression and } \\
\text { transcriptional decay } \\
\text { - } & \text { Defence against } \\
& \text { exogenous viruses } \\
\text { - } & \text { Transposon defence } \\
\text { - } & \\
& \text { Epigenetic regulation }\end{array}$ & $\begin{array}{c}\text { Imperfect complementarity } \\
\text { to target } \\
\text { RNase III enzymes for } \\
\text { biogenesis (Dicer and } \\
\text { Drosha) } \\
\text { Typically bind the 3'UTR of } \\
\text { target mRNA } \\
\text { AGO-dependent degradation } \\
\text { and translational repression } \\
\text { Chromatin modification } \\
\text { through targeting epigenetic } \\
\text { factors }\end{array}$ & $\begin{array}{c}\text { Dicer and } \\
\text { Drosha-independent } \\
\text { mechanisms also exist } \\
\text { Found in most } \\
\text { eukaryotes }\end{array}$ & $\begin{array}{c}\text { Trans-acting } \\
\text { asRNA }\end{array}$ & $\begin{array}{c}\text { Typically long } \\
\text { (100s-1000s of } \\
\text { nucleotides) }\end{array}$ & $\begin{array}{ll}\text { - } & \text { Translational } \\
\text { repression and } \\
\text { transcriptional decay } \\
\text { - } & \text { Defence against } \\
\text { - exogenous viruses } \\
\text { - } & \text { Transposon defence }\end{array}$ & $\begin{array}{c}\text { Imperfect complementarity } \\
\text { to target } \\
\text { Usually derived from } \\
\text { intergenic regions } \\
\text { Can target mRNA or protein } \\
\text { Hfq as a chaperone } \\
\text { RNase E, RNase Y or RNase } \\
\text { III-mediated cleavage }\end{array}$ & $\begin{array}{l}\text { Hfq is only present in } \\
\text { some bacteria } \\
\text { RNase E is only present } \\
\text { in Gram-negative } \\
\text { bacteria } \\
\text { RNase Y is only present } \\
\text { in Gram-positive bacteria }\end{array}$ \\
\hline siRNA & $\begin{array}{c}22-25 \\
\text { nucleotides }\end{array}$ & $\begin{array}{ll}\text { - } & \text { Translational } \\
\text { repression } \\
\text { and decay } \\
\text { - } & \text { Defence against } \\
\text { exogenous viruses } \\
\text { - } & \text { Transposon defence } \\
\text { - } & \text { Epigenetic regulation }\end{array}$ & $\begin{array}{c}\text { Perfect complementarity to } \\
\text { target } \\
\text { RNase III enzymes for } \\
\text { biogenesis (Dicer) } \\
\text { AGO-dependent degradation } \\
\text { Histone modification }\end{array}$ & $\begin{array}{l}\text { Found in most } \\
\text { eukaryotes }\end{array}$ & $\begin{array}{l}\text { Cis-acting } \\
\text { asRNA }\end{array}$ & Mostly short & $\begin{array}{ll}\text { - } & \text { Translational } \\
\text { repression and } \\
\text { transcriptional decay } \\
\text { - } & \text { Transposon defence } \\
- & \text { Regulation of plasmid } \\
\text { copy number, } \\
\text { conjugation and } \\
\text { phage life cycle } \\
\text { - } \\
\text { Environment-mediated } \\
\text { regulation of } \\
\text { gene expression }\end{array}$ & 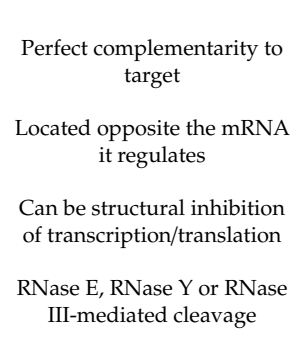 & 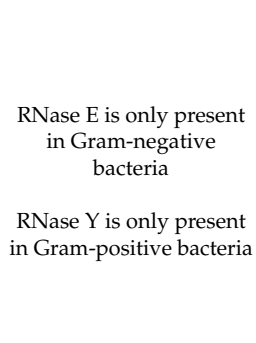 \\
\hline piRNA & $\begin{array}{c}\text { 24-31 } \\
\text { nucleotides }\end{array}$ & $\begin{array}{ll}\text { - } & \text { Transposon defence } \\
\text { in germline } \\
\text { - Transgenerational } \\
\text { epigenetic inheritance } \\
\text { - Expressed in } \\
\text { somatic cells and } \\
\text { bodily fluids where } \\
\text { role is unclear }\end{array}$ & $\begin{array}{c}\text { Perfect complementarity to } \\
\text { target for canonical piRNAs } \\
\text { Imperfect complementarity } \\
\text { to target for other piRNAs } \\
\text { Often derived from piRNA } \\
\text { clusters } \\
\text { PIWI-dependent degradation }\end{array}$ & $\begin{array}{l}\text { Found in metazoans } \\
\text { Biogenesis is highly } \\
\text { variable amongst } \\
\text { different organisms }\end{array}$ & $\begin{array}{c}\text { crRNA } \\
\text { tracrRNA }\end{array}$ & $\begin{array}{l}20 \text { nucleotide } \\
\text { spacers in } \\
\text { crRNA } \\
\text { Approx. } 100 \\
\text { nucleotides in } \\
\text { tracrRNA }\end{array}$ & $\begin{array}{l}\text { Defence against } \\
\text { invasive } \\
\text { bacteriophage } \\
\text { and plasmids }\end{array}$ & $\begin{array}{l}\text { crRNAs have perfect } \\
\text { complementarity to target } \\
\text { tracrRNAs have imperfect } \\
\text { complementarity } \\
\text { Derived from CRISPR loci } \\
\text { Cas9-dependent degradation }\end{array}$ & $\begin{array}{c}\text { Found in } \\
50 \% \text { of bacteria } \\
90 \% \text { of archaea }\end{array}$ \\
\hline
\end{tabular}


In eukaryotes, miRNAs and siRNAs are derived from longer precursor molecules and processed into smaller molecules of approximately 21 to 25 nucleotides in length [3]. Both miRNA and siRNA mediate post-transcriptional gene silencing through the RNA-induced silencing (RISC) complex and the AGO subfamily of Argonaute proteins. The key difference is that miRNAs can bind to targets with imperfect complementarity, enabling one miRNA to target hundreds of messenger RNAs (mRNAs), whereas siRNAs generally require perfect complementarity to their target sequence [4]. Additionally, the siRNA silencing mechanism can be amplified by the action of RNA-dependent RNA polymerases (RdRPs). These enzymes produce secondary siRNAs by using the target mRNA as a template $[5,6]$. However, it is unclear whether such amplification occurs in vertebrates, as they do not possess RdRP genes. miRNAs and siRNAs associated with AGO and RISC can act in the defence against exogenous viruses by targeting key viral genes $[7,8]$. Small RNAs also prevent transposon transcription through the direction of epigenetic modifications and heterochromatin formation $[9,10]$. In particular, the piRNA family of small non-coding RNAs, are a primary form of defence against transposons and are also critical for fertility in animals $[10,11]$. piRNAs mediate transcriptional silencing through the PIWI subfamily of Argonaute proteins. Silencing occurs via the ping-pong cycle, during which a piRNA-bound transposon is cleaved by PIWI, generating another piRNA of the opposite orientation [12]. piRNAs are thought to mediate transposon silencing through heterochromatin formation and de novo DNA methylation, although the precise mechanisms through which this occurs are not yet clear [13]. These classes of regulatory RNA are each reminiscent of the distinct classes of bacterial regulatory RNAs. However, evidence suggests that miRNAs specifically are the key mediators of inter-domain communications [14-16].

\section{1. miRNA Biogenesis}

miRNAs were first discovered in 1993 in Caenorhabditis elegans [17]. They are post-transcriptional gene regulators, typically 21-25 nucleotides in length, and are found in almost all plants and animals [18-20]. They are transcribed in the nucleus by RNA polymerase II to form a long pre-cursor primary miRNA molecule which creates a hairpin structure (Figure 1A) [21]. In animals, the hairpin is excised by the endonuclease Drosha and a shorter pre-miRNA hairpin molecule forms which is exported into the cytoplasm by exportin-5 [22,23]. The endonuclease Dicer then cleaves the terminal hairpin leaving an RNA duplex of approximately 22 nucleotides in length. Typically, one of these strands is preferentially loaded onto the RISC complex, directing the enzymatic complex to the target mRNA [24]. The RISC complex consists of the miRNA and an Argonaute protein, although there can also be many other binding partners [25]. The complex can either degrade the target or inhibit its translation, dependent on the level of complementarity [26]. miRNAs can additionally up-regulate the expression of the target mRNA, although this is less common [27]. miRNAs typically bind to the $3^{\prime}$ Untranslated Region (UTR) of the target mRNA with incomplete base pairing, often only requiring complementarity to the "seed sequence" of the miRNA, at nucleotides 2-8 [28]. This enables a single miRNA to have many target transcripts. 


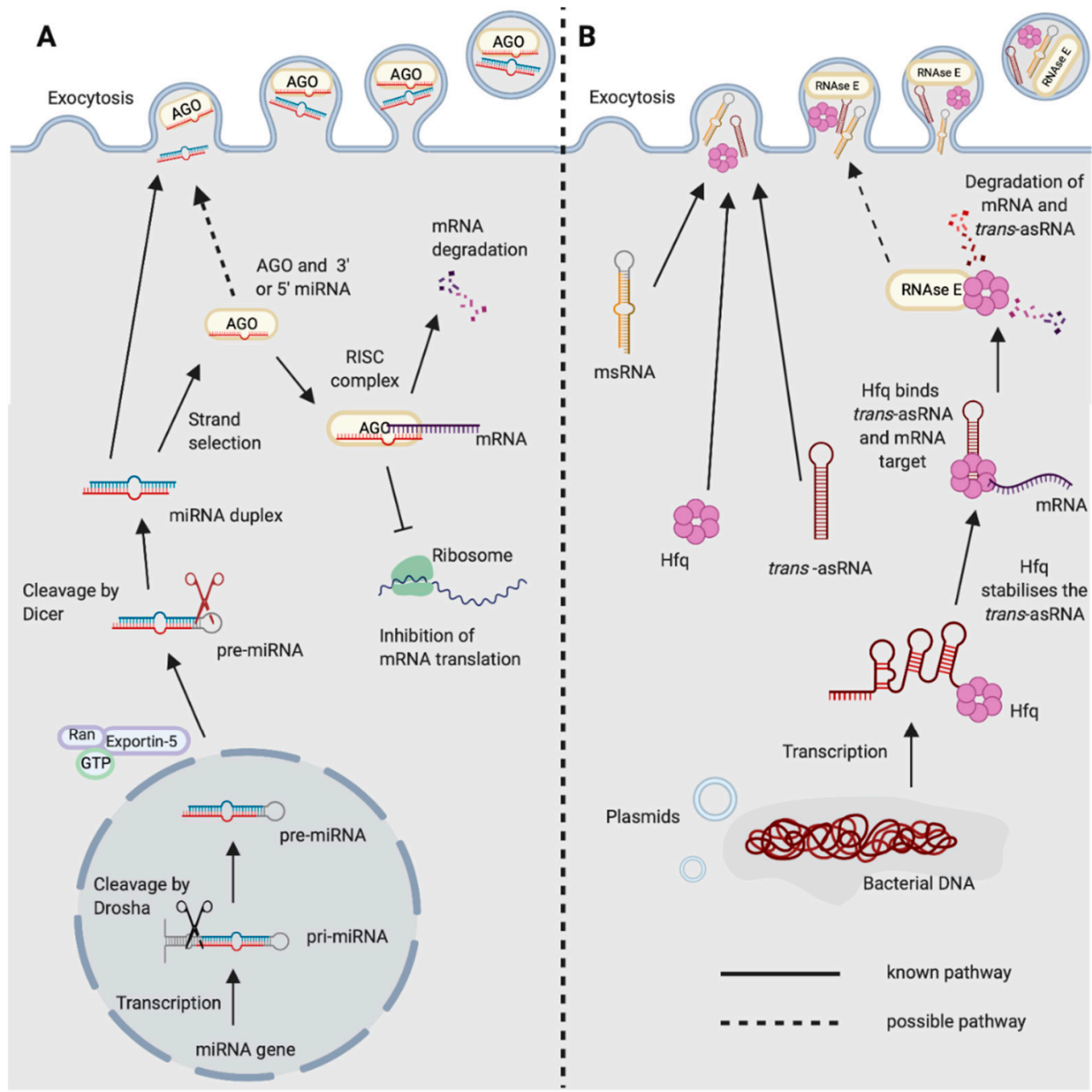

Figure 1. Biogenesis and functions of (A) miRNAs in eukaryotes and (B) trans-asRNAs in bacteria. (A) Eukaryotic miRNAs are transcribed in the nucleus into a pre-cursor primary-miRNA (pri-miRNA) transcript. The pri-miRNA is cleaved by Drosha (black scissors) to form a shorter hairpin, the pre-miRNA. The pre-miRNA is exported from the nucleus by exportin- 5 in conjunction with ran-GTP. In the cytoplasm, the pre-miRNA is cleaved further by Dicer (red scissors) to form a miRNA duplex. One strand from the miRNA duplex is preferentially loaded onto Argonaute (AGO) forming the RNA-induced Silencing Complex (RISC). The miRNA of the RISC complex facilitates binding to the target mRNA (requiring only partial complementarity). Catalytically active AGOs (AGO2 in humans) can cleave and degrade the mRNA target. The RISC complex can also inhibit ribosomal translation of mRNAs. Exocytosis of miRNAs in Extracellular Vesicles (EVs) has been shown in eukaryotes [14]. It is not yet known whether the miRNA could be loaded onto AGO prior to exocytosis. (B) Newly transcribed bacterial trans-asRNAs can be stabilised by Hfq. Hfq can also facilitate binding between the trans-asRNA and the mRNA target $[29,30]$. In Gram-negative bacteria, Hfq can facilitate binding of the trans-asRNA and mRNA to RNase E which degrades both the asRNA and mRNA [31]. It is unclear whether RNase E can be exported from bacteria, but it does possess a domain capable of binding the membrane of phospholipid vesicles in vitro [32]. Bacteria have been shown to export microRNA-size RNA (msRNA) and trans-asRNAs in EVs [33-35]. Hfq can also be exported from bacteria in EVs [36] Created with BioRender.com.

\section{2. miRNAs in Disease}

Currently, there are 1917 identified miRNA loci in the human genome, with 60\% of human protein-coding genes estimated to be regulated by at least one miRNA [37,38]. They form complex 
signalling networks which regulate important biological processes such as cell differentiation and proliferation, apoptosis, metabolism, the immune response, development and ageing [39-43]. Due to the critical roles of miRNAs in such a range of biological processes, they are also ideal targets for pathogens that need to alter their environment to establish infection. Host miRNAs play a fundamental role in shaping the innate and adaptive immune responses, and can also directly target pathogens and inhibit their replication [44-46]. Conversely, pathogens can also produce miRNAs to disrupt the immune response, facilitating their own survival [7,47]. Human Immunodeficiency Virus 1 (HIV-1) encodes a pre-miRNA sequence in its genome (HIV1-miR-H1). HIV-1 exploits the human host's miRNA processing machinery to convert this into a functional mature miRNA. This has critical roles in HIV-1 pathogenesis due to its repression of host anti-viral responses, including the host anti-viral miRNA, hsa-miR-149 [48-50]. Other viruses capable of producing miRNAs include Herpes Simplex 1, Epstein Barr virus and Cytomegalovirus [51]. Consequently, an increasing number of clinical trials are focusing on the therapeutic value of miRNAs in viral infections. There are also several active clinical trials investigating miRNAs in other human diseases including in autoimmunity, various cancers and cardiovascular disease ([52], and at clinicaltrials.gov).

\section{3. miRNAs and Bacteria}

The vast majority of studies concerning miRNAs have focused on the role of miRNAs in eukaryotes, or in viruses that exploit eukaryotic cell machinery [7,51,52]. However, an expanding area of research is now showing that miRNAs can alter the composition of the bacteria in the intestinal microbiota of mammalian hosts [14,16]. Dysbiosis of the intestinal microbiota has been demonstrated in an increasing number of diseases ranging from Inflammatory Bowel Disease and Multiple Sclerosis, to psychological disorders including Bipolar Disorder, Depression and Anxiety amongst many others [53-56]. The mechanisms by which these unfavourable changes occur are largely unclear. Whether miRNAs could play a role in interactions between the more distantly related eukaryotes and bacteria is an emerging concept that requires more thorough consideration.

\section{Regulatory RNAs in Bacteria}

Bacteria possess three key classes of regulatory molecules-(i) cis-acting $5^{\prime}$ element non-coding RNAs, (ii) trans-acting small non-coding asRNAs (trans-asRNAs), and (iii) cis-encoded antisense RNAs (cis-asRNAs). Cis-acting 5' element non-coding RNAs are typically present in the 5'UTR of the mRNA they regulate. Ligand binding induces structural changes in the non-coding RNA, that subsequently influences the transcription of the downstream gene. This type of RNA-mediated regulation includes riboswitches, thermoregulators and $\mathrm{pH}$ sensors [57]. Whereas, the bacterial trans-asRNAs and cis-asRNAs recognise their target sequence via complementary base pairing, akin to eukaryotic miRNAs, siRNAs and piRNAs. Eukaryotes and prokaryotes have utilised RNA-dependent mechanisms for various common functions including post-transcriptional gene regulation, as a defence against exogenous viral infections and as a defence against transposons (Table 1).

\subsection{Bacterial Regulatory RNAs}

Bacteria produce various classes of RNAs that can function as post-transcriptional gene regulators and can mediate protection against transposons and exogenous viruses $[57,58]$. The bacterial asRNAs regulate several critical processes including plasmid replication, conjugation, detoxification, quorum sensing, defence from transposable elements and the stress response [58-62]. A range of mechanisms are involved in RNA-mediated regulation of gene expression including transcription interference through the occlusion of promoters, degradation of sense transcripts, stabilisation of sense transcripts and regulation of translation. Overall, RNA-mediated repression of gene expression by cis and trans-asRNAs in bacteria is not well understood, in part due to the diverse mechanisms of action. 


\subsection{Cis-Acting asRNAs}

Cis-asRNAs are transcribed from the strand that is antisense to the gene that they regulate, and therefore harbour overlapping complementary regions to the target gene $[63,64]$. Many cis-asRNAs are involved in the regulation of mobile genetic elements such as plasmids, phages, and transposons [65]. Other cis-asRNAs regulate responses to environmental changes and are critical for bacterial fitness [66]. Cis-asRNAs are typically short and require perfect complementarity to their target [65].

\subsection{Trans-Acting asRNAs}

Trans-asRNAs regulate genes located elsewhere on the chromosome. Bacterial trans-asRNAs also include the trans-acting CRISPR RNAs (tracrRNAs) that function in conjunction with CRISPR RNAs (crRNAs) in defence against bacteriophage [67]. Trans-asRNAs in bacteria share many common functions with miRNAs in eukaryotes. Furthermore, they have similar recognition mechanisms, in that they only require partial complementarity to their target sequence $[57,64,68]$. Less is known about the precise mechanisms of regulatory RNAs in bacteria, and mechanisms appear to vary considerably across different species due to the lack of conservation of key proteins. This is particularly evident when comparing the mechanisms in Gram-positive and Gram-negative bacteria.

\section{4. asRNA-Mediated Regulation in Gram-Positive and Gram-Negative Bacteria}

Interactions between asRNAs and their target mRNA can result in either degradation, or the protection from nuclease recognition and increased mRNA stability [69-73]. In Gram-negative bacteria, this nuclease is thought to be primarily RNase E, the key nuclease of the degradosome, in which RNase E acts as a scaffold for the binding of other enzymes including the RNA helicase RhlB, and the $3^{\prime}-5^{\prime}$-exoribonuclease polynucleotide phosphorylase (PNPase) [74]. In Gram-positive bacteria, RNase $\mathrm{Y}$ is the key nuclease of the degradosome and is thought to be the primary nuclease of asRNA-mediated mRNA cleavage [74,75]. For many trans-asRNAs, the interaction with RNase $\mathrm{E}$ is mediated by the RNA chaperone protein, Hfq (Figure 1B) [29,30]. Hfq stabilises the trans-asRNA and facilitates binding between the trans-asRNA and its mRNA target, despite the limited complementarity in RNA sequence [72,76]. It also serves to protect many RNAs from degradation [77,78]. Hfq may also enable RNA export-due to its RNA binding properties and its ability to associate with, and create holes in, the lipid bilayers of liposomes and vesicles [79]. Hfq is widely conserved amongst bacteria, with around half of Gram-positive and Gram-negative bacteria expressing the protein [80]. In Gram-positive bacteria that do not possess RNase E, the role of Hfq is less clear, although in Listeria monocytogenes it has been shown to protect its target from nuclease degradation [81]. Hfq is also a recognised virulence factor in some Gram-negative bacteria including Salmonella typhimurium and Vibrio cholerae [82-84]. In addition to RNase E and RNase Y, RNase III is also involved in asRNA-mediated mRNA degradation, and RNase III is conserved amongst all bacteria due to its role in $16 \mathrm{~S}$ and $23 \mathrm{~S}$ ribosomal RNA (rRNA) maturation $[66,72,85]$.

\subsection{Trans-asRNAs in CRISPR}

The tracrRNA of CRISPR, a bacterial defence against bacteriophage and invasive nucleic acids is also an example of a trans-asRNA. Here, the tracrRNA and the crRNA together form the guide RNA that directs the enzymatic action of the CRISPR-associated (cas) endonuclease to the target sequence [86]. The target nucleic acid sequence is that of an invasive bacteriophage or plasmid and is complementary to the spacer regions found within the crRNA. This enables sequence-specific recognition and degradation of foreign DNA. In type II CRISPR-Cas systems, for the arrays that contain multiple spacers the tracrRNA directs RNase III to the crRNA leading to its maturation [87]. 


\section{Shared Features of Eukaryotic and Bacterial Regulatory RNA Pathways}

\subsection{A Conserved Protein Fold between AGO, PIWI and Cas}

The viral-derived RNase H-like protein superfamily is thought to have been a key driver of the evolution of complex life forms on the early earth, as it includes many essential enzymes in both eukaryotes and bacteria [88]. Members of the RNase H-like protein superfamily are mediators of many important processes including DNA replication, transposition, gene splicing, and the generation of adaptive immune responses [89]. The RNA interference (RNAi) pathways of eukaryotes and the CRISPR anti-viral defence of bacteria both rely on RNase H-like endonucleases. In RNAi, this is the Argonaute and PIWI-like proteins, and in CRISPR, the Cas proteins [89]. These enzymes all possess an $\mathrm{RNase} \mathrm{H}$ fold, one of the most ancient and abundant protein folds known [90]. At a glance, these distinct pathways and mechanisms can initially appear to be completely unrelated. However, there are many shared features of these pathways.

\subsection{CRISPR RNA and piRNA-Guided Immunity}

One of the most striking similarities between eukaryotic and prokaryotic regulatory RNA pathways is the crRNA-guided CRISPR immunity of prokaryotes and piRNA-guided immunity in metazoans. The piRNAs and crRNAs of these pathways each represent a form of genome-encoded trans-generational adaptive immunity. In prokaryotes, CRISPR mediates defence against invasive nucleic acids from bacteriophage and plasmids [67]. In metazoans, piRNA-mediated immunity is the primary defence mechanism against transposable elements in the germline [91]. The majority of piRNAs are derived from piRNA clusters [92]. Similarly, crRNAs are also derived from distinct regions in the prokaryotic genome, the CRISPR loci [67]. In prokaryotes, short sequences of the invasive DNA are integrated into the CRISPR loci by the Cas endonuclease, separated by repeat sequences. In eukaryotes, both invasive RNA and DNA viruses can be integrated into piRNA clusters [93,94]. Both piRNAs and crRNAs are classes of regulatory RNAs that are complementary in sequence to the invasive nucleic acid, and that guide an endonuclease complex to the foreign target sequence [94]. In CRISPR, this is the Cas endonuclease that is guided by crRNAs, whereas piRNAs guide the PIWI endonuclease to the target sequence. In contrast to CRISPR, piRNAs can also direct histone modifications that mediate gene silencing [95]. These pathways are prime examples of the parallel functions and mechanisms of the distinct regulatory RNA pathways in eukaryotes and bacteria.

\subsection{Shared Features of mRNA Decay in Eukaryotes and Bacteria}

In eukaryotes, newly synthesised mRNAs are characterised by a $5^{\prime} 7$-methylguanylate $\left(\mathrm{m}^{7} \mathrm{G}\right) \mathrm{cap}$ and 3' poly-adenylation [96]. General mRNA decay occurs due to decapping of the mRNAs and removal of the poly (A) tails in cytoplasmic Processing bodies (P-bodies) [97]. In bacteria, the degradosome is the key mediator of bulk RNA turnover, and newly synthesised bacterial mRNAs possess a $5^{\prime}$ triphosphate group that must be converted to a $5^{\prime}$ monophosphate group for efficient recognition by RNase E or RNase Y of the degradosome [98]. Interestingly, both miRNAs and siRNAs in eukaryotes are also characterised by $5^{\prime}$ monophosphate groups, and the enzyme responsible for this conversion in E. coli, $\mathrm{RppH}$, is closely related to DCP2 of the decapping complex in eukaryotes [99-101]. The DCP2 decapping complex is also known to be involved in miRNA-mediated gene silencing in eukaryotes [102]. The $5^{\prime}$ monophosphate may enable the association of miRNAs and siRNAs with the nucleases of the bacterial degradosomes. Whether this shared evolutionary relationship between decapping enzymes could also enable miRNA-mediated regulation of bacterial gene expression through the degradosome, is another interesting prospect. A further example of this shared relationship between eukaryotic and bacterial RNA decay pathways is also demonstrated by Hfq of the trans-asRNA pathway, and its likeness to the eukaryotic Sm proteins. 


\subsection{Bacterial Hfq is Reminiscent of Eukaryotic Decapping Proteins}

The function of Hfq is somewhat analogous to the RISC complex, as it facilitates interactions between trans-asRNAs and their target mRNAs [103]. Yet, it bears the most striking structural and functional similarities to the eukaryotic Sm and Sm-like proteins [104,105]. It contains the conserved Sm1 motif and, similar to the eukaryotic proteins, forms an oligomeric ring-shaped structure. Hfq facilitates the regulation of mRNA stability through interactions with trans-asRNAs, whereas in eukaryotes the Sm-like protein, Lsm1, is involved in mRNA decapping and degradation [106]. These conserved structural and functional components may enable trans-asRNAs of bacteria to interact with the mRNA decay machinery in eukaryotes. Alternatively, they may enable miRNAs that function through decapping enzymes to influence bacterial gene expression. Investigating the ability of eukaryotic regulatory RNAs to complex with Hfq or the bacterial degradosome, and of trans-asRNAs to interact with eukaryotic Sm-like proteins could reveal novel mechanisms of host-bacterial interactions.

\section{4. miRNAs Facilitate Inter-Kingdom Communications}

There are several examples of inter-kingdom communications mediated by miRNAs and miRNA-like molecules amongst the eukaryotes. The processes of RNA release and the mechanisms by which they remain resistant to degradation in the environment are critical to RNA-mediated inter-kingdom interactions. Extracellular Vesicles (EVs) containing RNA as cargo offer a route by which this communication could be mediated.

\subsection{EVs in Eukaryotes and Bacteria}

EVs are spherical membranous structures that are shed from the surface of cells. There are three main types of EVs in eukaryotes: exosomes, apoptotic blebs and shedding microvesicles, that vary in size and biogenesis [107]. The production of EVs is conserved across the domains of Archaea, Bacteria and Eukarya. In bacteria, these are sometimes referred to as Outer Membrane Vesicles (OMVs), Outer-Inner Membrane Vesicles (O-IMVs), or Membrane Vesicles (MVs) but will be referred to collectively as EVs from herein [108]. In both eukaryotes and prokaryotes, EVs appear to enable the shuttling of genetic information between cells, facilitating horizontal gene transfer (HGT) in bacteria and long-distance DNA and RNA transfer in eukaryotes [109-111]. Bacteria are known to export a range of RNAs in EVs including rRNA, transfer RNA (tRNA), transfer-messenger RNA (tmRNA), mRNA and most notably, some bacteria have even been shown to export trans-asRNAs, and microRNA-size RNAs (msRNAs) in EVs [33-35]. Many of the small RNAs found in bacterial EVs are often enriched compared to the cytoplasm of the cell that they are derived from $[112,113]$. Helminth parasites such as Schistosoma japonicum, Heligmosomoides bakeri and Trichuris muris also produce EVs containing RNA that have important immunomodulatory effects in the host [114-116]. Whilst, EVs from plants have been shown to enable the transfer of functional miRNAs from plants to mammals, representing a means by which plant substances in the human diet can directly regulate mammalian gene expression and immune function [117].

\subsection{Plant miRNAs in Inter-Kingdom Communications}

During initial studies, it was demonstrated that rice-derived miR-168a is stably present in human serum after a rice meal and that this can target human/mouse low-density lipoprotein receptor adapter protein 1 (LDLRAP1) mRNA, decreasing its expression in the liver [117]. Similar studies have detected other dietary-derived plant miRNAs in various animal tissues $[118,119]$. However, these studies remain controversial amid claims that these findings were due to sample contamination, and that the quantity detected was not biologically significant. Other studies have subsequently counteracted these criticisms (reviewed in [120]).

Supporting studies have detected plant-derived Exosome-like nanoparticles (ELNs) in grape, grapefruit, carrot and ginger [121]. These ELNs are resistant to degradation by acidic stomach-like 
solutions and were found to contain miRNAs; some of which share a seed sequence with known human miRNAs. As such, they offer a potential mechanism for the transport of functional plant-derived RNA molecules into heterologous hosts following consumption. However, further work is needed to confirm this concept. Plant siRNAs and miRNAs also serve important roles in plant immune responses, and influence interactions with various pathogens including fungi, viruses, bacteria and helminths (reviewed in [122]).

\subsection{Human and Plant miRNAs in EVs Can Modulate the Gut Microbiota}

Bacteria have been overlooked as potential targets for eukaryote-derived miRNAs, given their lack of known machinery necessary for the production and function of these molecules in eukaryotes. However, recent work has challenged this concept [14]. Their studies showed that host Intestinal Epithelial Cells (IECs) produced miRNA-containing EVs under healthy physiological conditions. Furthermore, these EVs were internalised by specific members of the intestinal microbiota, and the miRNAs within them found to co-localise with their nucleic acids and alter their growth [14]. Plant ELNs containing miRNAs are also internalised by specific members of the intestinal microbiota [16]. Ginger ELNs (GELNs) contain 109 mature miRNA sequences, which can increase the levels of Lactobacillaceae and inhibit the growth of Ruminococcaceae. In these studies, treatment of the probiotic bacterium, Lactobacillus rhamnosus (LGG) with GELNs led to reduced expression of 249 mRNAs. One of the GELN miRNAs, mdo-miR7267-3p was shown to target the LGG monooxygenase, YcnE, and alters tryptophan metabolism by increasing the production of Indole-3-carboxaldehyde (I3A) from tryptophan [16]. I3A is a ligand for the mouse aryl hydrocarbon receptor (AHR) and was sufficient to induce the production of IL-22, leading to an improvement in intestinal barrier function and an enhanced resistance to DSS-induced colitis [16]. This demonstrates the role of eukaryotic miRNAs in the regulation of the mammalian microbiota.

Furthermore, the periodontal pathogen Porphymonas gingivalis internalises GELNS through binding to a surface protein, hemin-binding protein 35 (HBP35). GELNs decrease the ability of $P$. gingivalis to attach, enter and proliferate in oral epithelial cells. Whilst, a GELN miRNA, aly-miR159a was shown to significantly reduce the expression of the gingipain toxin genes Rgp and Kgp [15]. This study signifies that plant miRNAs from the diet can potentially influence the disease outcome of a significant human pathogen, whilst offering a potential novel avenue by which the human microbiota can be modulated.

\subsection{The Microbiota Can Modulate Host miRNA Expression}

The interaction between the microbiota and miRNAs is a bi-directional relationship. Studies comparing the miRNA profiles of germ-free (GF) mice and conventionally raised mice show that the microbiota negatively regulates the expression of miR-10a by intestinal dendritic cells, in a TLR-TLR and MYD88-dependent pathway [123]. This in turn reduces the production of IL-12, an inducer of IFN- $\gamma$ and a driver of the Th1-type inflammatory immune responses. Consequently, limiting intestinal inflammation and improving barrier function under normal physiological conditions [123]. The microbiota also modulates the host miRNA profile through the production of bioactive metabolites. Polyphenols are found in plant products including seasonings, nuts and berries, and can be metabolised into bioactive urolithins by the gut microbiota. One such compound, urolithin A, induces an increase in miR-10a-5p expression and inhibits the activation and proliferation of CD4+ T cells through the down-regulation of Orai1 and STIM1/2 transcripts [124]. This mechanism may confer the anti-oxidative and anti-inflammatory effects shown by these foods. It is clear that the bacterial modulation of the host miRNA profile can occur through various distinct mechanisms, and that this is important in host-microbiota interactions. 


\section{Mechanisms for RNA-based Communication between Eukaryotes and Bacteria}

\subsection{Bacterial asRNAs Can Hijack Eukaryotic RNAi Pathways}

Several studies have illustrated the presence of msRNAs in bacterial genomes using bioinformatic approaches over the last decade [125-127]. These bacterial-derived msRNAs can be delivered into host cells and incorporate into the eukaryotic host's miRNA-processing machinery, thereby serving important functional roles for the bacterium $[47,128]$. For example, an msRNA derived from an RNA stem-loop in Mycobacterium marinum associates with eukaryotic RISC [128]. Furthermore, Salmonella can release RNA into the cytosol of infected IECs, and this RNA is processed by human AGO2, in a Dicer-independent fashion, into small functional msRNAs of 22 nucleotides in length. One of these miRNA-like molecules, Sal-1, serves as a critical virulence factor, facilitating the intracellular replication and survival of the bacteria [47]. These data demonstrate a role for bacterial-derived RNA molecules in the successful colonisation by human pathogens.

Similarly, it was observed that the periodontal pathogens Aggregatibacter actinomycetemcomitans, P. gingivalis, and Treponema denticola produce msRNAs in EVs that could enter eukaryotic fibroblast cells in vitro [129]. Exogenous transfection of some of the most abundantly expressed msRNAs by these bacteria led to a decrease in the anti-inflammatory cytokines IL-5 and IL-13 by Jurkat T cells [129]. These pathogens have been implicated in periodontitis, which is driven by the inflammatory response to the bacteria of the oral microbiota [130]. This work, therefore, highlights bacterial RNAs as a potential novel therapeutic target.

Additionally, trans-acting asRNAs OxyS and DsrA from E. coli, can impair C. elegans chemosensory behaviour and longevity through down-regulation of che-2 and the diacylglycerol lipase gene F42G9.6, respectively [35]. This is an RDE-4 dependent process, with RDE-4 being a key component of C. elegans RNAi, that processes dsRNA by complexing with Dicer and subsequently worm argonaute, RDE-1 [35,131]. In E. coli OxyS and DsrA function to co-ordinate the stress response through the regulation of the protein sigma factor RpoS in an Hfq-dependent manner [132]. Together, these studies show that a number of bacteria are known to produce RNAs that could mimic eukaryotic regulatory RNAs and feed into eukaryotic RNAi processing pathways. In addition, bacterial asRNAs can also have additional distinct functions in the eukaryotic host. Whether these relationships extend to host-microbiota interactions is an intriguing prospect that warrants further study. Investigating whether the production of RNA by members of the microbiota can modulate relationships with the host, and vice versa will be a key part of translating correlative microbiota studies into clinical benefits.

\subsection{Proposal of Mechanisms for Regulatory RNAs in Inter-domain Communications}

This review of the current literature leads us to propose two potential mechanisms by which regulatory RNAs could mediate bi-directional communications between eukaryotes and bacteria. (1) RNA molecules produced by one organism could integrate into one of the distinct regulatory RNA pathways present in the other. For example, the RNAs produced by Salmonella become functional upon processing by eukaryotic RNAi machinery, such as AGO2 and Dicer [47]. This is also true for E. coli, which exploits C. elegans RNAi machinery to regulate eukaryotic gene expression through its own bacterial trans-asRNAs [35] (2) RNAs are exported in EVs in conjunction with the molecules required for their functioning in the recipient (Figure 2). This is shown by Hfq which is exported in EVs by Yersinia pestis, and in an Acinetobacter baumannii Hfq mutant which displays reduced EV production [36,133]. Furthermore, eukaryotic Argonaute has also been detected in EVs [134]. These mechanisms could also occur in combination, with both host and recipient molecules important in inter-domain regulatory RNA-mediated communications. 
A Microbiota-eukaryote interaction

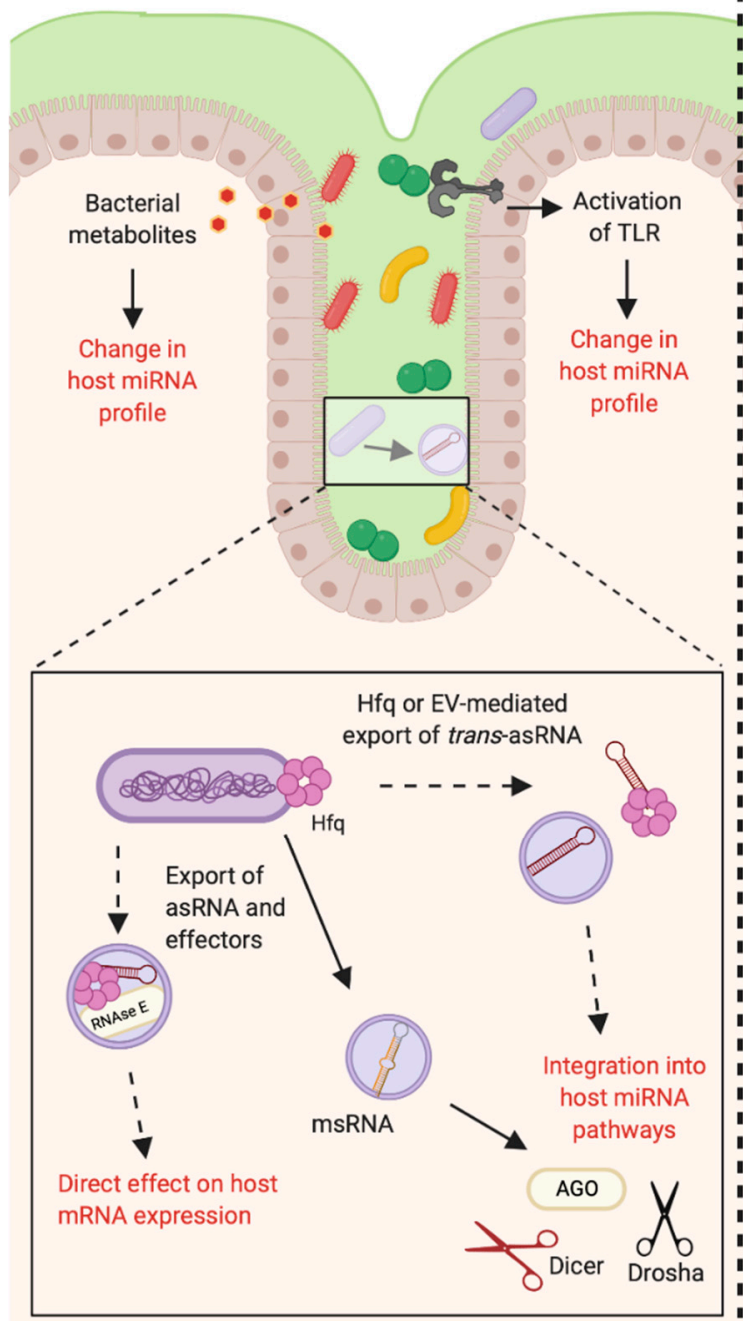

B

\section{Eukaryote-microbiota interaction}

Plant ELNs
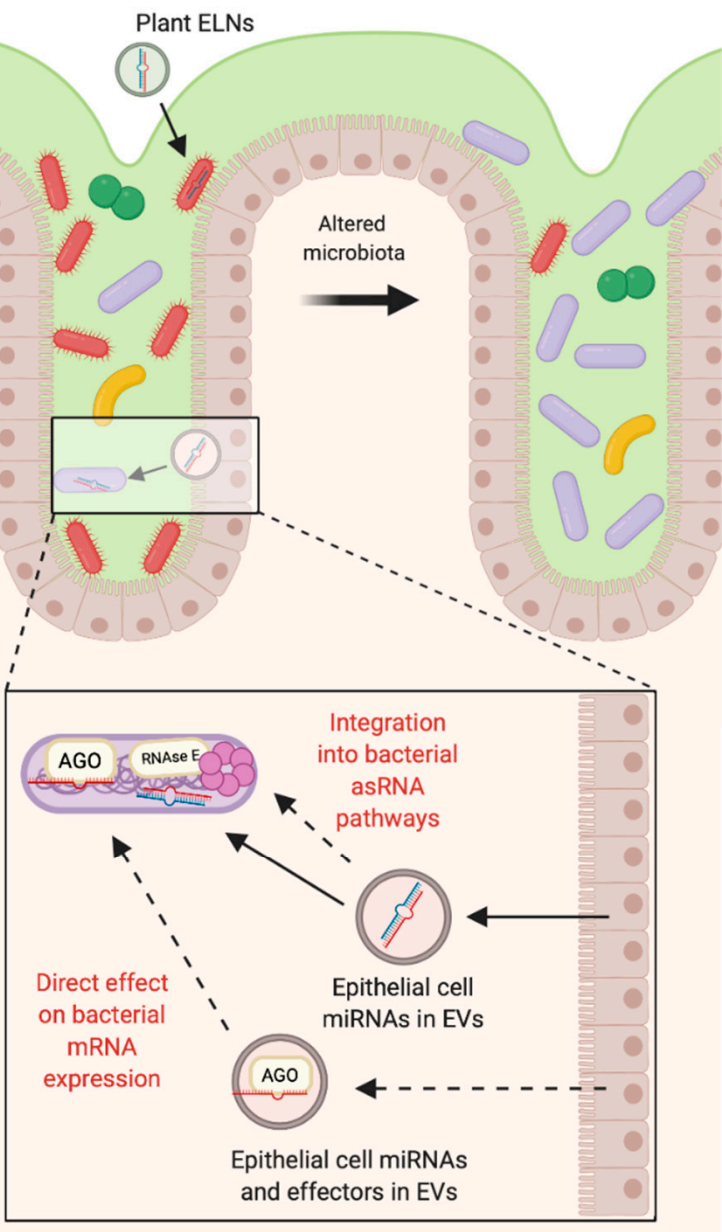

known pathway

- - - - possible pathway

Figure 2. RNA-mediated communications between the mammalian host and the bacteria of the gastrointestinal microbiota. (A) The bacteria of the mammalian intestinal microbiota can indirectly alter the host miRNA profile through the production of metabolites and activation of Toll-like Receptors (TLRs). It is known that bacteria can produce microRNA-size RNAs (msRNAs) in Extracellular Vesicles (EVs) that can integrate into host miRNA pathways [47]. Other RNAs such as trans-asRNAs could be exported in vesicles and could similarly integrate into host pathways. It is also possible that asRNAs could be exported along with their effectors in EVs (such as Hfq and RNase E) and could directly influence host gene expression. EV-independent export of asRNAs could be mediated by Hfq, as Hfq can create holes in the bacterial cell membrane [79]. (B) Plant exosome-like nanoparticles (ELNs) from diet and EVs from intestinal epithelial cells containing miRNAs can enter members of the microbiota and influence bacterial gene expression and growth $[14,16]$. These miRNAs could be exported with effectors such as Argonaute (AGO) to directly alter bacterial gene expression. Alternatively, eukaryotic miRNAs could become functional upon integration into existing bacterial asRNA regulatory pathways BioRender.com.

\section{Future Directions}

Development of a robust miRNA-mediated bacterial phenotype in a genetically tractable bacterial species in vitro will enable the interrogation of the mechanisms of action. Researchers could seek to 
knock-out or inhibit the expression of key molecules such as bacterial Hfq, to determine whether these molecules are required for miRNA function in the bacterial recipient. Further interrogation of the contents of EVs containing miRNAs in eukaryotes could also yield insights into their functions in bacteria. Furthermore, we note that many diseases are associated with perturbations to both the host miRNA profile and host microbiotas. This is evident in cancers including Colorectal cancer, Ovarian cancer and Hepatic carcinoma, and among a wide range of other diseases including Autistic Spectrum Disorder, Crohn's Disease and Multiple Sclerosis [135-138]. Future investigations could seek to determine if miRNAs are responsible for the microbiota perturbations in these contexts. We anticipate that this approach could establish causality in several correlative studies.

\section{Concluding Remarks}

Eukaryotic regulatory RNAs have recently been implicated as regulators of bacterial growth. However, due to the lack of proposed mechanisms for these interactions these studies remain controversial. Here, we sample the significant body of research illustrating the role of regulatory RNAs in various inter-kingdom communications. From human-pathogen interactions and human-microbiota interactions to diet-microbiota interactions and the health implications of dietary-derived miRNAs, this research is significant in both medicine and agriculture. Amongst eukaryotes, it is clear that regulatory RNA pathways are largely conserved between animals and plants. However, there are significant gaps in the literature with regards to the molecular mechanisms of the proposed interactions between eukaryotes and bacteria. We anticipate that our careful comparisons of the molecular pathways of RNA-mediated gene regulation in eukaryotes and bacteria could significantly aid developments in the field of inter-domain communications. As EVs and regulatory RNAs are produced either directly or indirectly by all forms of life, we propose that RNA encapsulated in EVs could enable communication between all organisms, even the distantly related eukaryotes and bacteria. Future studies should seek to investigate whether eukaryotic miRNAs that influence bacterial growth could feed into the RNA processing pathways of bacteria, or whether they are exported with eukaryotic RNAi machinery. This will be particularly informative for the treatment of microbiota-associated diseases and bacterial pathogens and is essential for validating the concept of regulatory RNAs as a truly universal language.

\section{Authors Contribution}

E.L. did the original draft preparation, writing and construction of figures, A.-M.F., S.G.-J., R.K.G. and I.S.R. were involved in writing, reviewing and editing the manuscript. All authors have read and agreed to the published version of the manuscript.

Funding: EL is supported by the joint A*STAR-University of Manchester PhD program. RKG holds a Wellcome Trust Investigator Award Z10661/Z/18/Z.

Conflicts of Interest: The authors declare no conflict of interest.

\section{References}

1. Fang, Y.; Fullwood, M. Roles, Functions, and mechanisms of long non-coding RNAs in cancer. Genom. Proteom. Bioinform. 2016, 14, 42-54. [CrossRef]

2. Maston, G.; Evans, S.; Green, M. Transcriptional regulatory elements in the human genome. Annu. Rev. Genom. Hum. Genet. 2006, 7, 29-59. [CrossRef]

3. Carthew, R.; Sontheimer, E. Origins and Mechanisms of miRNAs and siRNAs. Cell 2009, 136, 642-655. [CrossRef] [PubMed]

4. Lam, J.; Chow, M.; Zhang, Y.; Leung, S. siRNA versus miRNA as therapeutics for gene silencing. Mol. Ther. Nucleic Acids 2015, 4, e252. [CrossRef] [PubMed]

5. Sijen, T.; Fleenor, J.; Simmer, F.; Thijssen, K.; Parrish, S.; Timmons, L.; Plasterk, R.; Fire, A. On the role of RNA amplification in dsRNA-triggered gene silencing. Cell 2001, 107, 465-476. [CrossRef] 
6. Zhang, C.; Ruvkun, G. New insights into siRNA amplification and RNAi. RNA Biol. 2012, 9, $1045-1049$. [CrossRef]

7. Kaul, D.; Khanna, A. Suman Evidence and nature of a novel miRNA encoded by HIV-1. Proc. Indian Acad. Sci. 2006, 72, 91-95.

8. Zhou, R.; Rana, T. RNA-based mechanisms regulating host-virus interactions. Immunol. Rev. 2013, 253, 97-111. [CrossRef]

9. Lippman, Z.; Martienssen, R. The role of RNA interference in heterochromatic silencing. Nature 2004, 431, 364-370. [CrossRef]

10. Shalgi, R.; Pilpel, Y.; Oren, M. Repression of transposable-elements-A microRNA anti-cancer defense mechanism? Trends Genet. 2010, 26, 253-259. [CrossRef]

11. Castañeda, J.; Genzor, P.; Bortvin, A. piRNAs, transposon silencing, and germline genome integrity. Mutat. Res./Fundam. Mol. Mech. Mutagenesis 2011, 714, 95-104.

12. Czech, B.; Hannon, G. One loop to rule them all: The Ping-Pong cycle and piRNA-guided silencing. Trends Biochem. Sci. 2016, 41, 324-337. [CrossRef] [PubMed]

13. Le Thomas, A.; Rogers, A.; Webster, A.; Marinov, G.; Liao, S.; Perkins, E.; Hur, J.; Aravin, A.; Toth, K. Piwi induces piRNA-guided transcriptional silencing and establishment of a repressive chromatin state. Genes Dev. 2013, 27, 390-399. [CrossRef] [PubMed]

14. Liu, S.; da Cunha, A.; Rezende, R.; Cialic, R.; Wei, Z.; Bry, L.; Comstock, L.; Gandhi, R.; Weiner, H. The host shapes the gut microbiota via fecal MicroRNA. Cell Host Microbe 2016, 19, 32-43. [CrossRef]

15. Sundaram, K.; Miller, D.; Kumar, A.; Teng, Y.; Sayed, M.; Mu, J.; Lei, C.; Sriwastva, M.; Zhang, L.; Jun, Y.; et al. Plant-derived exosomal nanoparticles inhibit pathogenicity of Porphyromonas gingivalis. iScience 2019, 21, 308-327. [CrossRef]

16. Teng, Y.; Ren, Y.; Sayed, M.; Hu, X.; Lei, C.; Kumar, A.; Hutchins, E.; Mu, J.; Deng, Z.; Luo, C.; et al. Plant-derived exosomal MicroRNAs shape the gut microbiota. Cell Host Microbe 2018, 24, 637-652.e8. [CrossRef]

17. Lee, R.; Feinbaum, R.; Ambros, V. The C. elegans heterochronic gene lin-4 encodes small RNAs with antisense complementarity to lin-14. Cell 1993, 75, 843-854. [CrossRef]

18. Bruscella, P.; Bottini, S.; Baudesson, C.; Pawlotsky, J.; Feray, C.; Trabucchi, M. Viruses and miRNAs: More friends than foes. Front. Microbiol. 2017, 8, 824. [CrossRef]

19. Lee, H.; Li, L.; Gu, W.; Xue, Z.; Crosthwaite, S.; Pertsemlidis, A.; Lewis, Z.; Freitag, M.; Selker, E.; Mello, C.; et al. Diverse pathways generate MicroRNA-like RNAs and dicer-independent small interfering RNAs in Fungi. Mol. Cell 2010, 38, 803-814. [CrossRef]

20. Wahid, F.; Shehzad, A.; Khan, T.; Kim, Y. MicroRNAs: Synthesis, mechanism, function, and recent clinical trials. Biochim. Et Biophys. Acta (Bba) Mol. Cell Res. 2010, 1803, 1231-1243. [CrossRef]

21. Lee, Y.; Ahn, C.; Han, J.; Choi, H.; Kim, J.; Yim, J.; Lee, J.; Provost, P.; Rådmark, O.; Kim, S.; et al. The nuclear RNase III Drosha initiates microRNA processing. Nature 2003, 425, 415-419. [CrossRef] [PubMed]

22. Lee, Y. MicroRNA maturation: Stepwise processing and subcellular localization. EMBO J. 2002, 21, 4663-4670. [CrossRef]

23. Yi, R.; Qin, Y.; Macara, I.; Cullen, B. Exportin-5 mediates the nuclear export of pre-microRNAs and short hairpin RNAs. Genes Dev. 2003, 17, 3011-3016. [CrossRef] [PubMed]

24. Kuchenbauer, F.; Mah, S.; Heuser, M.; McPherson, A.; Rüschmann, J.; Rouhi, A.; Berg, T.; Bullinger, L.; Argiropoulos, B.; Morin, R.; et al. Comprehensive analysis of mammalian miRNA* species and their role in myeloid cells. Blood 2011, 118, 3350-3358. [CrossRef] [PubMed]

25. Rivas, F.; Tolia, N.; Song, J.; Aragon, J.; Liu, J.; Hannon, G.; Joshua-Tor, L. Purified Argonaute2 and an siRNA form recombinant human RISC. Nat. Struct. Mol. Biol. 2005, 12, 340-349. [CrossRef]

26. Zeng, Y.; Yi, R.; Cullen, B. MicroRNAs and small interfering RNAs can inhibit mRNA expression by similar mechanisms. Proc. Natl. Acad. Sci. USA 2003, 100, 9779-9784. [CrossRef] [PubMed]

27. Vasudevan, S. Posttranscriptional upregulation by MicroRNAs. Wiley Interdiscip. Rev. RNA 2011, 3, 311-330. [CrossRef]

28. Lewis, B.; Shih, I.; Jones-Rhoades, M.; Bartel, D.; Burge, C. Prediction of mammalian MicroRNA targets. Cell 2003, 115, 787-798. [CrossRef]

29. Baek, Y.; Jang, K.; Lee, H.; Yoon, S.; Baek, A.; Lee, K.; Kim, D. The bacterial endoribonuclease Rnase E can cleave RNA in the absence of the RNA chaperone Hfq. J. Biol. Chem. 2019, 294, 16465-16478. [CrossRef] 
30. Ikeda, Y.; Yagi, M.; Morita, T.; Aiba, H. Hfq binding at RhlB-recognition region of Rnase E is crucial for the rapid degradation of target mRNAs mediated by sRNAs in Escherichia coli. Mol. Microbiol. 2010, 79, 419-432. [CrossRef]

31. De Lay, N.; Gottesman, S. Rnase E finds some sRNAs Stimulating. Mol. Cell 2012, 47, 825-826. [CrossRef] [PubMed]

32. Khemici, V.; Poljak, L.; Luisi, B.; Carpousis, A. The Rnase E of Escherichia coli is a membrane-binding protein. Mol. Microbiol. 2008, 70, 799-813. [PubMed]

33. Dauros-Singorenko, P.; Blenkiron, C.; Phillips, A.; Swift, S. The functional RNA cargo of bacterial membrane vesicles. FEMS Microbiol. Lett. 2018, 365. [CrossRef]

34. Ghosal, A.; Upadhyaya, B.; Fritz, J.; Heintz-Buschart, A.; Desai, M.; Yusuf, D.; Huang, D.; Baumuratov, A.; Wang, K.; Galas, D.; et al. The extracellular RNA complement of Escherichia coli. MicrobiologyOpen 2015, 4, 252-266. [CrossRef] [PubMed]

35. Liu, H.; Wang, X.; Wang, H.; Wu, J.; Ren, J.; Meng, L.; Wu, Q.; Dong, H.; Wu, J.; Kao, T.; et al. Escherichia coli noncoding RNAs can affect gene expression and physiology of Caenorhabditis elegans. Nat. Commun. 2012, 3, 1073. [CrossRef] [PubMed]

36. Eddy, J.; Gielda, L.; Caulfield, A.; Rangel, S.; Lathem, W. Production of outer membrane vesicles by the plague pathogen Yersinia pestis. PloS ONE 2014, 9, e107002. [CrossRef]

37. Friedman, R.; Farh, K.; Burge, C.; Bartel, D. Most mammalian mRNAs are conserved targets of microRNAs. Genome Res. 2008, 19, 92-105. [CrossRef]

38. Mirbase.org. Mirbase. 2020. Available online: http://www.mirbase.org/summary.shtml?org=hsa (accessed on 10 April 2020).

39. Colamatteo, A.; Micillo, T.; Bruzzaniti, S.; Fusco, C.; Garavelli, S.; De Rosa, V.; Galgani, M.; Spagnuolo, M.; Di Rella, F.; Puca, A.; et al. Metabolism and autoimmune responses: The microRNA connection. Front. Immunol. 2019, 10, 1969. [CrossRef]

40. Hwang, H.; Mendell, J. MicroRNAs in cell proliferation, cell death, and tumorigenesis. Br. J. Cancer 2006, 94, 776-780. [CrossRef]

41. Ivey, K.; Srivastava, D. microRNAs as Developmental Regulators. Cold Spring Harb. Perspect. Biol. 2015, 7, a008144. [CrossRef]

42. Slattery, M.; Mullany, L.; Sakoda, L.; Wolff, R.; Samowitz, W.; Herrick, J. Dysregulated genes and miRNAs in the apoptosis pathway in colorectal cancer patients. Apoptosis 2018, 23, 237-250. [CrossRef] [PubMed]

43. Smith-Vikos, T.; Slack, F. MicroRNAs and their roles in aging. J. Cell Sci. 2012, 125, 7-17. [CrossRef] [PubMed]

44. Bai, X.; Nicot, C. miR-28-3p Is a cellular restriction factor that inhibits human T cell leukemia virus, type 1 (HTLV-1) replication and virus infection. J. Biol. Chem. 2015, 290, 5381-5390. [CrossRef] [PubMed]

45. He, J.; Ji, Y.; Li, A.; Zhang, Q.; Song, W.; Li, Y.; Huang, H.; Qian, J.; Zhai, A.; Yu, X.; et al. MiR-122 directly inhibits human papillomavirus E6 gene and enhances interferon signaling through blocking suppressor of cytokine signaling 1 in SiHa cells. PloS ONE 2014, 9, e108410. [CrossRef] [PubMed]

46. Zhou, X.; Li, X.; Wu, M. miRNAs reshape immunity and inflammatory responses in bacterial infection. Signal Transduct. Target. Ther. 2018, 3, 1-13. [CrossRef]

47. Gu, H.; Zhao, C.; Zhang, T.; Liang, H.; Wang, X.; Pan, Y.; Chen, X.; Zhao, Q.; Li, D.; Liu, F.; et al. Salmonella produce microRNA-like RNA fragment Sal-1 in the infected cells to facilitate intracellular survival. Sci. Rep. 2017, 7, 1-12. [CrossRef]

48. Hariharan, M.; Scaria, V.; Pillai, B.; Brahmachari, S. Targets for human encoded microRNAs in HIV genes. Biochem. Biophys. Res. Commun. 2005, 337, 1214-1218. [CrossRef]

49. Kaul, D.; Ahlawat, A.; Gupta, S. HIV-1 genome-encoded hiv1-mir-H1 impairs cellular responses to infection. Mol. Cell. Biochem. 2008, 323, 143-148. [CrossRef]

50. Kogan, M.; Rappaport, J. HIV-1 accessory protein Vpr: Relevance in the pathogenesis of HIV and potential for therapeutic intervention. Retrovirology 2011, 8, 25. [CrossRef]

51. Piedade, D.; Azevedo-Pereira, J. The role of microRNAs in the pathogenesis of herpes virus infection. Viruses 2016, 8, 156. [CrossRef]

52. Hanna, J.; Hossain, G.; Kocerha, J. The potential for microRNA therapeutics and clinical research. Front. Genet. 2019, 10, 478. [CrossRef] [PubMed] 
53. De Palma, G.; Lynch, M.; Lu, J.; Dang, V.; Deng, Y.; Jury, J.; Umeh, G.; Miranda, P.; Pigrau Pastor, M.; Sidani, S.; et al. Transplantation of fecal microbiota from patients with irritable bowel syndrome alters gut function and behavior in recipient mice. Sci. Transl. Med. 2017, 9, eaaf6397. [CrossRef] [PubMed]

54. Evans, S.; Bassis, C.; Hein, R.; Assari, S.; Flowers, S.; Kelly, M.; Young, V.; Ellingrod, V.; McInnis, M. The gut microbiome composition associates with bipolar disorder and illness severity. J. Psychiatr. Res. 2017, 87, 23-29. [CrossRef] [PubMed]

55. Pinto-Sanchez, M.; Hall, G.; Ghajar, K.; Nardelli, A.; Bolino, C.; Lau, J.; Martin, F.; Cominetti, O.; Welsh, C.; Rieder, A.; et al. Probiotic Bifidobacterium longum NCC3001 reduces depression scores and alters brain activity: A pilot study in patients with irritable bowel syndrome. Gastroenterology 2017, 153, 448-459.e8. [CrossRef]

56. Zheng, P.; Zeng, B.; Zhou, C.; Liu, M.; Fang, Z.; Xu, X.; Zeng, L.; Chen, J.; Fan, S.; Du, X.; et al. Gut microbiome remodeling induces depressive-like behaviors through a pathway mediated by the host's metabolism. Mol. Psychiatry 2016, 21, 786-796. [CrossRef]

57. Saberi, F.; Kamali, M.; Najafi, A.; Yazdanparast, A.; Moghaddam, M. Natural antisense RNAs as mRNA regulatory elements in bacteria: A review on function and applications. Cell. Mol. Biol. Lett. 2016, $21,6$. [CrossRef]

58. Ellis, M.; Haniford, D. Riboregulation of bacterial and archaeal transposition. Wiley Interdiscip. Rev. RNA 2016, 7, 382-398. [CrossRef]

59. Holmqvist, E.; Wagner, E. Impact of bacterial sRNAs in stress responses. Biochem. Soc. Trans. 2017, 45, 1203-1212. [CrossRef]

60. Olaya-Abril, A.; Luque-Almagro, V.; Pérez, M.; López, C.; Amil, F.; Cabello, P.; Sáez, L.; Moreno-Vivián, C.; Roldán, M. Putative small RNAs controlling detoxification of industrial cyanide-containing wastewaters by Pseudomonas pseudoalcaligenes CECT5344. PLoS ONE 2019, 14, e212032. [CrossRef]

61. Saramago, M.; Bárria, C.; Arraiano, C.; Domingues, S. Ribonucleases, antisense RNAs and the control of bacterial plasmids. Plasmid 2015, 78, 26-36. [CrossRef]

62. Shao, Y.; Bassler, B. Quorum-sensing non-coding small RNAs use unique pairing regions to differentially control mRNA targets. Mol. Microbiol. 2012, 83, 599-611. [CrossRef] [PubMed]

63. Kawai, G. Translational control by antisense RNA, bacteria. Encycl. Syst. Biol. 2013, 2282-2285. [CrossRef]

64. Gottesman, S.; Storz, G. Bacterial small RNA regulators: Versatile roles and rapidly evolving variations. Cold Spring Harb. Perspect. Biol. 2010, 3, a003798. [CrossRef] [PubMed]

65. Brantl, S. Regulatory mechanisms employed by cis-encoded antisense RNAs. Curr. Opin. Microbiol. 2007, 10, 102-109. [CrossRef]

66. Georg, J.; Hess, W. cis-antisense RNA, another level of gene regulation in bacteria. Microbiol. Mol. Biol. Rev. 2011, 75, 286-300. [CrossRef]

67. Rath, D.; Amlinger, L.; Rath, A.; Lundgren, M. The CRISPR-Cas immune system: Biology, mechanisms and applications. Biochimie 2015, 117, 119-128. [CrossRef]

68. Dugar, G.; Leenay, R.; Eisenbart, S.; Bischler, T.; Aul, B.; Beisel, C.; Sharma, C. CRISPR RNA-dependent binding and cleavage of endogenous RNAs by the Campylobacter jejuni Cas9. Mol. Cell 2018, 69, 893-905.e7. [CrossRef]

69. Lee, E.; Groisman, E. An antisense RNA that governs the expression kinetics of a multifunctional virulence gene. Mol. Microbiol. 2010, 76, 1020-1033. [CrossRef]

70. Lioliou, E.; Sharma, C.; Caldelari, I.; Helfer, A.; Fechter, P.; Vandenesch, F.; Vogel, J.; Romby, P. Global regulatory functions of the Staphylococcus aureus endoribonuclease III in gene expression. PLoS Genet. 2012, 8, e1002782. [CrossRef]

71. Sayed, N.; Jousselin, A.; Felden, B. A cis-antisense RNA acts in trans in Staphylococcus aureus to control translation of a human cytolytic peptide. Nat. Struct. Mol. Biol. 2011, 19, 105-112. [CrossRef]

72. Šetinová, D.; Šmídová, K.; Pohl, P.; Musić, I.; Bobek, J. RNase III-Binding-mRNAs revealed novel complementary transcripts in streptomyces. Front. Microbiol. 2018, 8, 2693. [CrossRef] [PubMed]

73. Stazic, D.; Lindell, D.; Steglich, C. Antisense RNA protects mRNA from RNase E degradation by RNA-RNA duplex formation during phage infection. Nucleic Acids Res. 2011, 39, 4890-4899. [CrossRef] [PubMed]

74. Cho, K. The structure and function of the gram-positive bacterial RNA degradosome. Front. Microbiol. 2017, 8,154 . [CrossRef] [PubMed] 
75. Durand, S.; Gilet, L.; Bessières, P.; Nicolas, P.; Condon, C. Three essential ribonucleases-Rnase Y, J1, and III-Control the abundance of a majority of Bacillus subtilis mRNAs. PloS Genet. 2012, 8, e1002520. [CrossRef]

76. Viegas, S.; Silva, I.; Saramago, M.; Domingues, S.; Arraiano, C. Regulation of the small regulatory RNA MicA by ribonuclease III: A target-dependent pathway. Nucleic Acids Res. 2010, 39, 2918-2930. [CrossRef]

77. Holmqvist, E.; Reimegård, J.; Sterk, M.; Grantcharova, N.; Römling, U.; Wagner, E. Two antisense RNAs target the transcriptional regulator CsgD to inhibit curli synthesis. EMBO J. 2010, 29, 1840-1850. [CrossRef]

78. Moll, I.; Afonyushkin, T.; Vytvytska, O.; Kaberdin, V.; BLÄSI, U. Coincident Hfq binding and RNase E cleavage sites on mRNA and small regulatory RNAs. RNA 2003, 9, 1308-1314. [CrossRef]

79. Malabirade, A.; Morgado-Brajones, J.; Trépout, S.; Wien, F.; Marquez, I.; Seguin, J.; Marco, S.; Velez, M.; Arluison, V. Membrane association of the bacterial riboregulator Hfq and functional perspectives. Sci. Rep. 2017, 7, 1-12. [CrossRef]

80. Faner, M.; Feig, A. Identifying and characterizing Hfq-RNA interactions. Methods 2013, 63, $144-159$. [CrossRef]

81. Nielsen, J.; Lei, L.; Ebersbach, T.; Olsen, A.; Klitgaard, J.; Valentin-Hansen, P.; Kallipolitis, B. Defining a role for Hfq in Gram-positive bacteria: Evidence for Hfq-dependent antisense regulation in Listeria monocytogenes. Nucleic Acids Res. 2009, 38, 907-919. [CrossRef]

82. Chao, Y.; Vogel, J. The role of Hfq in bacterial pathogens. Curr. Opin. Microbiol. 2010, 13, 24-33. [CrossRef] [PubMed]

83. Ding, Y.; Davis, B.; Waldor, M. Hfq is essential for Vibrio cholerae virulence and downregulates $\sigma$ E expression. Mol. Microbiol. 2004, 53, 345-354. [CrossRef] [PubMed]

84. Sittka, A.; Pfeiffer, V.; Tedin, K.; Vogel, J. The RNA chaperone Hfq is essential for the virulence of Salmonella typhimurium. Mol. Microbiol. 2007, 63, 193-217. [CrossRef] [PubMed]

85. Condon, C.; Putzer, H. The phylogenetic distribution of bacterial ribonucleases. Nucleic Acids Res. 2002, 30, 5339-5346. [CrossRef]

86. Deltcheva, E.; Chylinski, K.; Sharma, C.; Gonzales, K.; Chao, Y.; Pirzada, Z.; Eckert, M.; Vogel, J.; Charpentier, E. CRISPR RNA maturation by trans-encoded small RNA and host factor Rnase III. Nature 2011, 471, $602-607$. [CrossRef]

87. Karvelis, T.; Gasiunas, G.; Miksys, A.; Barrangou, R.; Horvath, P.; Siksnys, V. crRNA and tracrRNA guide Cas9-mediated DNA interference in Streptococcus thermophilus. RNA Biol. 2013, 10, 841-851. [CrossRef]

88. Moelling, K.; Broecker, F. The reverse transcriptase-RNase H: From viruses to antiviral defense. Ann. N. Y. Acad. Sci. 2015, 1341, 126-135. [CrossRef]

89. Moelling, K.; Broecker, F.; Russo, G.; Sunagawa, S. RNase H as gene modifier, driver of evolution and antiviral defense. Front. Microbiol. 2017, 8, 1745. [CrossRef]

90. Majorek, K.; Dunin-Horkawicz, S.; Steczkiewicz, K.; Muszewska, A.; Nowotny, M.; Ginalski, K.; Bujnicki, J. The RNase H-like superfamily: New members, comparative structural analysis and evolutionary classification. Nucleic Acids Res. 2014, 42, 4160-4179. [CrossRef]

91. Tóth, K.; Pezic, D.; Stuwe, E.; Webster, A. The piRNA pathway guards the germline genome against transposable elements. Non-Coding RNA Reprod. Syst. 2015, 886, 51-77.

92. Yamanaka, S.; Siomi, M.; Siomi, H. piRNA clusters and open chromatin structure. Mob. DNA $2014,5,22$. [CrossRef] [PubMed]

93. Horie, M.; Honda, T.; Suzuki, Y.; Kobayashi, Y.; Daito, T.; Oshida, T.; Ikuta, K.; Jern, P.; Gojobori, T.; Coffin, J.; et al. Endogenous non-retroviral RNA virus elements in mammalian genomes. Nature 2010, 463, 84-87. [CrossRef] [PubMed]

94. Ophinni, Y.; Palatini, U.; Hayashi, Y.; Parrish, N. piRNA-guided CRISPR-like immunity in eukaryotes. Trends Immunol. 2019, 40, 998-1010. [CrossRef] [PubMed]

95. Aravin, A.; Bourc'his, D. Small RNA guides for de novo DNA methylation in mammalian germ cells. Genes Dev. 2008, 22, 970-975. [CrossRef]

96. Gallie, D. The cap and poly(A) tail function synergistically to regulate mRNA translational efficiency. Genes Dev. 1991, 5, 2108-2116. [CrossRef]

97. Kushner, S. mRNA Decay in prokaryotes and eukaryotes: Different approaches to a similar problem. Int. Union Biochem. Mol. Biol. Life 2004, 56, 585-594. [CrossRef] 
98. Laalami, S.; Zig, L.; Putzer, H. Initiation of mRNA decay in bacteria. Cell. Mol. Life Sci. 2013, 71, 1799-1828. [CrossRef]

99. Deana, A.; Celesnik, H.; Belasco, J. The bacterial enzyme RppH triggers messenger RNA degradation by $5^{\prime}$ pyrophosphate removal. Nature 2008, 451, 355-358. [CrossRef]

100. Dunckley, T.; Parker, R. The DCP2 protein is required for mRNA decapping in Saccharomyces cerevisiae and contains a functional MutT motif. EMBO J. 1999, 18, 5411-5422. [CrossRef]

101. Wang, Q.; Zhang, D.; Guan, Z.; Li, D.; Pei, K.; Liu, J.; Zou, T.; Yin, P. DapF stabilizes the substrate-favoring conformation of RppH to stimulate its RNA-pyrophosphohydrolase activity in Escherichia Coli. Nucleic Acids Res. 2018, 46, 6880-6892. [CrossRef]

102. Rehwinkel, J.; Behm-Ansmant, I.; Gatfield, D.; Izaurralde, E. A crucial role for GW182 and the DCP1:DCP2 decapping complex in miRNA-mediated gene silencing. RNA 2005, 11, 1640-1647. [CrossRef] [PubMed]

103. Hoekzema, M.; Romilly, C.; Holmqvist, E.; Wagner, E. Hfq-dependent mRNA unfolding promotes sRNA -based inhibition of translation. EMBO J. 2019, 38, e101199. [CrossRef] [PubMed]

104. Møller, T.; Franch, T.; Højrup, P.; Keene, D.; Bächinger, H.; Brennan, R.; Valentin-Hansen, P. Hfq: A bacterial Sm-like protein that mediates RNA-RNA interaction. Mol. Cell 2002, 9, 23-30. [CrossRef]

105. Sauter, C.; Basquin, J.; Suck, D. Sm-like proteins in Eubacteria: The crystal structure of the Hfq protein from Escherichia Coli. Nucleic Acids Res. 2003, 31, 4091-4098. [CrossRef] [PubMed]

106. Chowdhury, A.; Tharun, S. Activation of decapping involves binding of the mRNA and facilitation of the post-binding steps by the Lsm1-7-Pat1 complex. RNA 2009, 15, 1837-1848. [CrossRef]

107. Woith, E.; Fuhrmann, G.; Melzig, M. Extracellular vesicles-Connecting Kingdoms. Int. J. Mol. Sci. 2019, 20, 5695. [CrossRef]

108. Gill, S.; Catchpole, R.; Forterre, P. Extracellular membrane vesicles in the three domains of life and beyond. Fems Microbiol. Rev. 2018, 43, 273-303. [CrossRef]

109. Kawamura, Y.; Yamamoto, Y.; Sato, T.; Ochiya, T. Extracellular vesicles as trans-genomic agents: Emerging roles in disease and evolution. Cancer Sci. 2017, 108, 824-830. [CrossRef]

110. Renelli, M.; Matias, V.; Lo, R.; Beveridge, T. DNA-containing membrane vesicles of Pseudomonas aeruginosa PAO1 and their genetic transformation potential. Microbiology 2004, 150, 2161-2169. [CrossRef]

111. Yaron, S.; Kolling, G.; Simon, L.; Matthews, K. Vesicle-mediated transfer of virulence genes from Escherichia coli O157:H7 to other enteric bacteria. Appl. Environ. Microbiol. 2000, 66, 4414-4420. [CrossRef]

112. Malabirade, A.; Habier, J.; Heintz-Buschart, A.; May, P.; Godet, J.; Halder, R.; Etheridge, A.; Galas, D.; Wilmes, P.; Fritz, J. The RNA complement of outer membrane vesicles from Salmonella enterica serovar typhimurium under distinct culture conditions. Front. Microbiol. 2018, 9, 2015. [CrossRef] [PubMed]

113. Resch, U.; Tsatsaronis, J.; Le Rhun, A.; Stübiger, G.; Rohde, M.; Kasvandik, S.; Holzmeister, S.; Tinnefeld, P.; Wai, S.; Charpentier, E. A two-component regulatory system impacts extracellular membrane-derived vesicle production in group A streptococcus. mBio 2016, 7, e00207-16. [CrossRef] [PubMed]

114. Buck, A.; Coakley, G.; Simbari, F.; McSorley, H.; Quintana, J.; Le Bihan, T.; Kumar, S.; Abreu-Goodger, C.; Lear, M.; Harcus, Y.; et al. Exosomes secreted by nematode parasites transfer small RNAs to mammalian cells and modulate innate immunity. Nat. Commun. 2014, 5, 5488. [CrossRef] [PubMed]

115. Shears, R.; Bancroft, A.; Hughes, G.; Grencis, R.; Thornton, D. Extracellular vesicles induce protective immunity against Trichuris muris. Parasite Immunol. 2018, 40, e12536. [CrossRef]

116. Wang, L.; Li, Z.; Shen, J.; Liu, Z.; Liang, J.; Wu, X.; Sun, X.; Wu, Z. Exosome-like vesicles derived by Schistosoma japonicum adult worms mediates M1 type immune- activity of macrophage. Parasitol. Res. 2015, 114, 1865-1873. [CrossRef]

117. Zhang, L.; Hou, D.; Chen, X.; Li, D.; Zhu, L.; Zhang, Y.; Li, J.; Bian, Z.; Liang, X.; Cai, X.; et al. Exogenous plant MIR168a specifically targets mammalian LDLRAP1: Evidence of cross-kingdom regulation by microRNA. Cell Res. 2011, 22, 107-126. [CrossRef]

118. Liang, G.; Zhu, Y.; Sun, B.; Shao, Y.; Jing, A.; Wang, J.; Xiao, Z. Assessing the survival of exogenous plant microRNA in mice. Food Sci. Nutr. 2014, 2, 380-388. [CrossRef]

119. Liang, H.; Zhang, S.; Fu, Z.; Wang, Y.; Wang, N.; Liu, Y.; Zhao, C.; Wu, J.; Hu, Y.; Zhang, J.; et al. Effective detection and quantification of dietetically absorbed plant microRNAs in human plasma. J. Nutr. Biochem. 2015, 26, 505-512. [CrossRef]

120. Li, Z.; Xu, R.; Li, N. MicroRNAs from plants to animals, do they define a new messenger for communication? Nutr. Metab. 2018, 15, 68. [CrossRef] 
121. Mu, J.; Zhuang, X.; Wang, Q.; Jiang, H.; Deng, Z.; Wang, B.; Zhang, L.; Kakar, S.; Jun, Y.; Miller, D.; et al. Interspecies communication between plant and mouse gut host cells through edible plant derived exosome-like nanoparticles. Mol. Nutr. Food Res. 2014, 58, 1561-1573. [CrossRef]

122. Islam, W.; Noman, A.; Qasim, M.; Wang, L. Plant responses to pathogen attack: Small RNAs in focus. Int. J. Mol. Sci. 2018, 19, 515. [CrossRef] [PubMed]

123. Xue, X.; Feng, T.; Yao, S.; Wolf, K.; Liu, C.; Liu, X.; Elson, C.; Cong, Y. Microbiota downregulates dendritic cell expression of miR-10a, which targets IL-12/IL-23p40. J. Immunol. 2011, 187, 5879-5886. [CrossRef] [PubMed]

124. Zhang, S.; Al-Maghout, T.; Cao, H.; Pelzl, L.; Salker, M.; Veldhoen, M.; Cheng, A.; Lang, F.; Singh, Y. Gut bacterial metabolite Urolithin A (UA) mitigates Ca2+ entry in T cells by regulating miR-10a-5p. Front. Immunol. 2019, 10, 1737. [CrossRef] [PubMed]

125. Dang, T.; Tyagi, S.; D'Cunha, G.; Bhave, M.; Crawford, R.; Ivanova, E. Computational prediction of microRNAs in marine bacteria of the genus Thalassospira. PloS ONE 2019, 14, e0212996. [CrossRef] [PubMed]

126. Kang, S.; Choi, J.; Lee, Y.; Hong, S.; Lee, H. Identification of microRNA-size, small RNAs in Escherichia coli. Curr. Microbiol. 2013, 67, 609-613. [CrossRef]

127. Lee, H.; Hong, S. Analysis of microRNA-size, small RNAs in Streptococcus mutans by deep sequencing. FEMS Microbiol. Lett. 2011, 326, 131-136. [CrossRef]

128. Furuse, Y.; Finethy, R.; Saka, H.; Xet-Mull, A.; Sisk, D.; Smith, K.; Lee, S.; Coers, J.; Valdivia, R.; Tobin, D.; et al. Search for MicroRNAs expressed by intracellular bacterial pathogens in infected mammalian cells. PLoS ONE 2014, 9, e106434. [CrossRef]

129. Choi, J.; Kim, S.; Hong, S.; Lee, H. Secretable small RNAs via outer membrane vesicles in periodontal pathogens. J. Dent. Res. 2017, 96, 458-466. [CrossRef]

130. Cekici, A.; Kantarci, A.; Hasturk, H.; Van Dyke, T. Inflammatory and immune pathways in the pathogenesis of periodontal disease. Periodontology 2000 2013, 64, 57-80. [CrossRef]

131. Raman, P.; Zaghab, S.; Traver, E.; Jose, A. The double-stranded RNA binding protein RDE-4 can act cell autonomously during feeding RNAi in C. elegans. Nucleic Acids Res. 2017, 45, 8463-8473. [CrossRef]

132. Liu, J.; Bittker, J.; Lonshteyn, M.; Liu, D. Functional dissection of sRNA translational regulators by nonhomologous random recombination and In Vivo selection. Chem. Biol. 2005, 12, 757-767. [CrossRef] [PubMed]

133. Kuo, H.; Chao, H.; Liao, P.; Hsu, L.; Chang, K.; Tung, C.; Chen, C.; Liou, M. Functional characterization of Acinetobacter baumannii lacking the RNA chaperone Hfq. Front. Microbiol. 2017, 8, 2068. [CrossRef] [PubMed]

134. Chow, F.; Koutsovoulos, G.; Ovando-Vázquez, C.; Neophytou, K.; Bermúdez-Barrientos, J.; Laetsch, D.; Robertson, E.; Kumar, S.; Claycomb, J.; Blaxter, M.; et al. Secretion of an Argonaute protein by a parasitic nematode and the evolution of its siRNA guides. Nucleic Acids Res. 2019, 47, 3594-3606. [CrossRef] [PubMed]

135. Allegra, A.; Musolino, C.; Tonacci, A.; Pioggia, G.; Gangemi, S. Interactions between the MicroRNAs and microbiota in cancer development: Roles and therapeutic opportunities. Cancers 2020, 12, 805. [CrossRef]

136. Ambrozkiewicz, F.; Karczmarski, J.; Kulecka, M.; Paziewska, A.; Niemira, M.; Zeber-Lubecka, N.; Zagorowicz, E.; Kretowski, A.; Ostrowski, J. In search for interplay between stool microRNAs, microbiota and short chain fatty acids in Crohn's disease-A preliminary study. BMC Gastroenterol. 2020, 20, 1-18. [CrossRef]

137. Kimura, K.; Hohjoh, H.; Yamamura, T. The role for exosomal microRNAs in disruption of regulatory T cell homeostasis in multiple sclerosis. J. Exp. Neurosci. 2018, 12, 117906951876489. [CrossRef]

138. Ragusa, M.; Santagati, M.; Mirabella, F.; Lauretta, G.; Cirnigliaro, M.; Brex, D.; Barbagallo, C.; Domini, C.; Gulisano, M.; Barone, R.; et al. Potential associations among alteration of salivary miRNAs, saliva microbiome structure, and cognitive impairments in Autistic children. Int. J. Mol. Sci. 2020, 21, 6203. [CrossRef]

Publisher's Note: MDPI stays neutral with regard to jurisdictional claims in published maps and institutional affiliations. 